началь 5-го мжсяца беременности-кровотеченіе изь матки и преждевременные роды; плодь живой, длиной 24 сятм., соотвьтствующій наqалу 5-го мъсяца береленнссти. Изь полости матки выпло кровяныхь сгустковт съ полвецра. Матка затьиь сокрапалась вяло, но посльродовой періодь прошель благошолучно.

H. Какуикинг.

225. М. Головчинеръ.-0 предлежаніи пляценты.-(Мецицина. 1898 г., 시잉 14 и 15).

Статья представляеть сводку мнъній по этому вопросу, высказанныхъ на одном' изъ засъданій конгресса нъмецихъ гинеко-

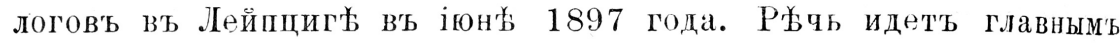
образомъ сбъ этіологіи и льчченіи placentae praeviae. Въ каqествъ этіологическаго момента большинствомь отмъчался эндометрить а также атрофія слизистой оболочки матки. Съ анатомической точки зрғнія placenta praevia разсматривалась не столью, какъ результать непосредственнаго ирикрұпленія яйца у внугренняго зъва, сколько какь результать неправильнаго разрастанія отпадаюей оболочки. При льченіи главное вниманіе обращается на кровотеченіе, для борьбы сь которымь иримбняегея тампонація влагалища (или кольпейризь матки), разрывъ пузыря и повороть.

\title{
H. Какуикино.
}

226. С. И. Кузьминъ.-Къ вопросу о пузырно-влагалищныхъ свищяхъ и ихъ оперативномъ льченіи.--(Больничн. Газ. Боткина, 1898 г. 샤응 3 и 4, стр. 87 и 147).

За девять льть (1889-1897 гг.) в’ь Саратовской губернской земской больниц в на 1004 гинекологическихъ больныхъ, подвергшихея операпіямь, съ пузырно-влагалищными свищами было 44 $(4,36 \%)$. Изъ этого числа 33 были крестьянки $(75 \%)$. Наичаще были в'ъ возрасть 21--25 л'ьть. Наичаще причиной образованія свищей были неправильности родового акта, а затьит инфекція. Наичаще свищи сшивались посль' сплошного, широкаго окровавливанія краевъ; слизистая пузыря въ повъ не захватывалась. Однажды были окровавлены не самыя стьнки свища, а слизистыя рукава на извъстномь отдаленіи оть свища; олнажды примҺъненъ лоскутный способъ; два раза-еpisiocleisis. Шзы почти исключительно шелковые, иногда металлическіе. Снимались на 6-8 дни. Постоянно иримҺнялся катетерь а̀ demeure, удаляемый на 9-10 дни. Посль⿱ оцнократнаго сшиванія зажили свищи в'ь 21 случағ $\left(47,74^{\circ} \%\right)$, посль двукратнаго къ 3 случаяхь $\left(6,81^{\%} \%\right)$, 